Article

\title{
Metaphylogenomic and Potential Functionality of the Limpet Patella pellucida's Gastrointestinal Tract Microbiome
}

\author{
Magda Dudek, Jessica Adams, Martin Swain, Matthew Hegarty, Sharon Huws and \\ Joe Gallagher * \\ Institute of Biological, Environmental \& Rural Sciences (IBERS), Aberystwyth University, \\ Gogerddan, Aberystwyth, Ceredigion, Wales SY23 3EE, UK; E-Mails: mad27@aber.ac.uk (M.D.); \\ jaa@aber.ac.uk (J.A.); mts11@aber.ac.uk (M.S.); ayh@aber.ac.uk (M.H.); hnh@aber.ac.uk (S.H.) \\ * Author to whom correspondence should be addressed; E-Mail: jbg@aber.ac.uk;
} Tel.: +44-0-1970-823-123.

External Editor: Weizhong Li

Received: 28 July 2014; in revised form: 30 September 2014 / Accepted: 11 October 2014 / Published: 20 October 2014

\begin{abstract}
This study investigated the microbial diversity associated with the digestive tract of the seaweed grazing marine limpet Patella pellucida. Using a modified indirect DNA extraction protocol and performing metagenomic profiling based on specific prokaryotic marker genes, the abundance of bacterial groups was identified from the analyzed metagenome. The members of three significantly abundant phyla of Proteobacteria, Firmicutes and Bacteroidetes were characterized through the literature and their predicted functions towards the host, as well as potential applications in the industrial environment assessed.
\end{abstract}

Keywords: Patella pellucida; limpet; mollusc; microbes; symbiosis; metagenomics; bioenergy; biorefining; seaweed; macroalgae

\section{Introduction}

Patella pellucida (Linnaeus, 1758), commonly known as the blue-rayed limpet or peacock's feathers [1], is a key seaweed grazer growing up to $15 \mathrm{~mm}$ in length and present on almost all Atlantic European coasts [2]. This small mollusc is a parasite of brown algae (mainly Laminaria digitata) and 
is often found buried in a self-digested hole within the stem of the seaweed (Figure 1). Brown algae are the main diet of the blue-rayed limpet. This limpet begins its life cycle when the seaweed accumulates high levels of sugars and ends when level of sugars decrease [3]. In order to digest and assimilate the polymeric carbohydrates present in the seaweed, including alginic acid, laminarin, fucoidan and cellulose [4], the limpet has developed very efficient enzymatic systems that, as with most herbivorous land and marine animals [5-7], is likely to involve a contribution by symbiotic microorganisms present in the digestive tract. Living in the open sea waters and being continuously exposed to predation, adult P. pellucida and its larvae are also likely to be protected by a chemical defense mechanism, often originated from stable endogenous bacterial communities [8].

Figure 1. P. pellucida grazing on a stem of L. digitata.

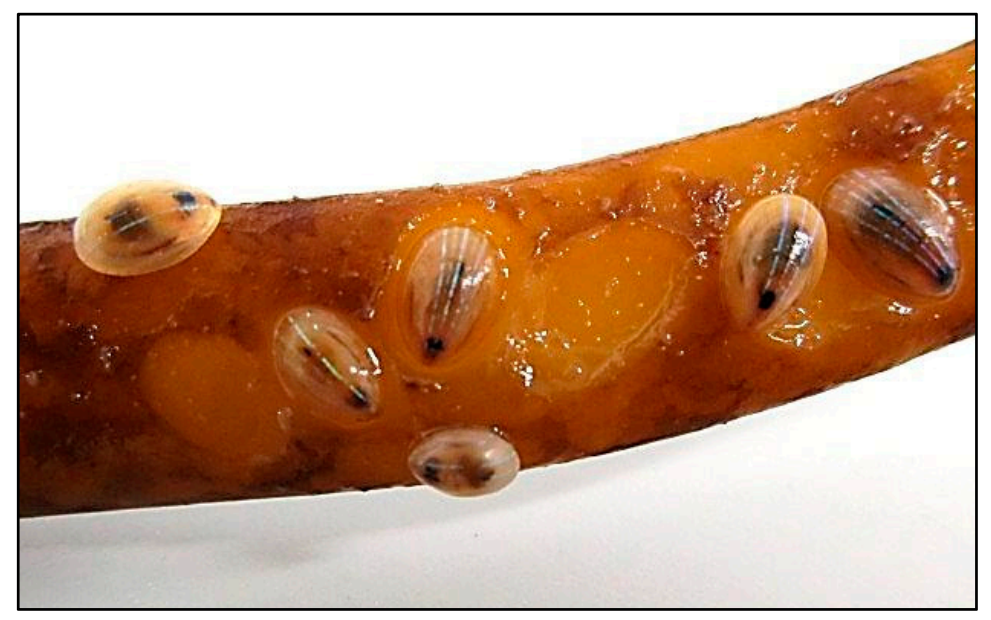

Symbiotic microorganisms associated with marine animals, both invertebrates such as sea snails, sea cucumbers, sea urchins [9-11] as well as vertebrates e.g., marine iguanas or sea cows [6,7], have recently become a focus for research leading to the discovery of various bioactive compounds exploitable by industry. By possessing a large arsenal of enzymes which display unique properties, e.g., stability in high salt concentrations, adaptation to cold temperatures, extreme $\mathrm{pH}$ tolerance as well as specificity for a broad range of substrates [12], some of these beneficial microbes have the potential to improve the efficiency of biomass conversion, a main bottleneck in today's biorefinery processes [13]. Particularly with the rapid development of blue biotechnology, based on marine-derived feedstock (e.g., micro and macro algae, waste from seafood processing), there is a growing interest in the applications of such microbial biocatalysts [14]. Symbiotic microorganisms, originally defending their marine animal host from predators, are now also seen as a potential source of novel drugs including new forms of antibiotics and anticancer treatments [15]. With new discoveries coming to light every year, microbial symbiosis in the marine ecosystem appears to be an untapped source of many other bio-compounds, which can be now better studied thanks to advanced molecular methods such as metagenomics [16].

Recent developments in using metagenomics offer a powerful alternative to culture dependent methods, providing an opportunity to study genomes of microbes that to date are uncultivable in the laboratory [17]. High-throughput metagenomic approaches have given great insights into the diversity, and function of microbial communities hosted by marine animals, expanding our knowledge on 
the biotechnological potential of prokaryotic populations inhabiting these hardly accessible, host-dependent niches $[11,18,19]$. Many metagenomic projects are based on an initial and crucial step which involves extraction of DNA [20]. Obtaining good quality microbial metagenomic DNA from samples where the target community is associated with an animal host (such as P. pellucida) can be problematic. This is mainly due to the contamination of prokaryotic material with eukaryotic cell-derived nucleic acids, introducing a significant bias in the analysis of the metagenomic reads, leading to the underestimation of microbial community size and composition [21]. The successful construction of metagenomic libraries from environmental samples therefore often relies on targeted cell separation prior to DNA extraction, which should not only reduce contamination by host DNA but also provide a high molecular weight and a satisfactory recovery rate of output DNA. This process, called indirect DNA extraction has several clear advantages over direct extraction of total DNA, such as yielding longer fragments of DNA, improving its purity and avoiding "noise" in the metagenomic sequence reads [22]. Reports in the literature describe various attempts to separate microbial communities from environmental samples using, e.g., density gradients [18], gel electrophoresis [23] or filtration [24]. None of these methods have been suitable to date as a universal protocol for indirect DNA extraction and there is always a risk that their application may result in underestimation of microbial diversity within the sample.

In this study a modified protocol for the indirect extraction of prokaryotic DNA was developed and applied to samples derived from $P$. pellucida's digestive tract. Extracted DNA was used for the construction of shotgun metagenomic libraries, which have been sequenced and analysed using Metagenomic Phylogenetic Analysis (MetaPhlAn), a powerful, new taxonomic classifier based on prokaryotic clade-specific marker genes [25,26]. Metagenomic analysis of the phylogenetic profiles and a prediction of the microbial functional roles in P. pellucida is the first step in assessing their potential for exploitation in the industrial environment.

\section{Results and Discussion}

Results of the MetaPhlAn analysis revealed a diverse microbial community in the P. pellucida's gastrointestinal tract (Figure 2). The predominant phylum in the microbial metagenome was the phylum Proteobacteria, with $38.8 \%$ relative abundance. The second predominant bacterial lineage, constituting $21.2 \%$, was identified as phylum Firmicutes and was followed by Tenericutes, Bacteroidetes and Spirochaetes, accounting respectively for $10.5 \%, 7.9 \%$ and $6.3 \%$ relative abundance. Less prevalent phyla were the Fusobacteria (4.6\%) and archaeal phylum Euryarcheota (4\%). Finally, representing $<1 \%$ of the total abundance, were phyla such as Thermotogae, Cyanobacteria, Aquificae, Crenarcheota, Chlamydiae, Actinobacteria and others. 
Figure 2. Phylum level classification of the P. pellucida gastrointestinal tract microbiome where the percentages are the relative abundances estimated by MetaPhlAn.

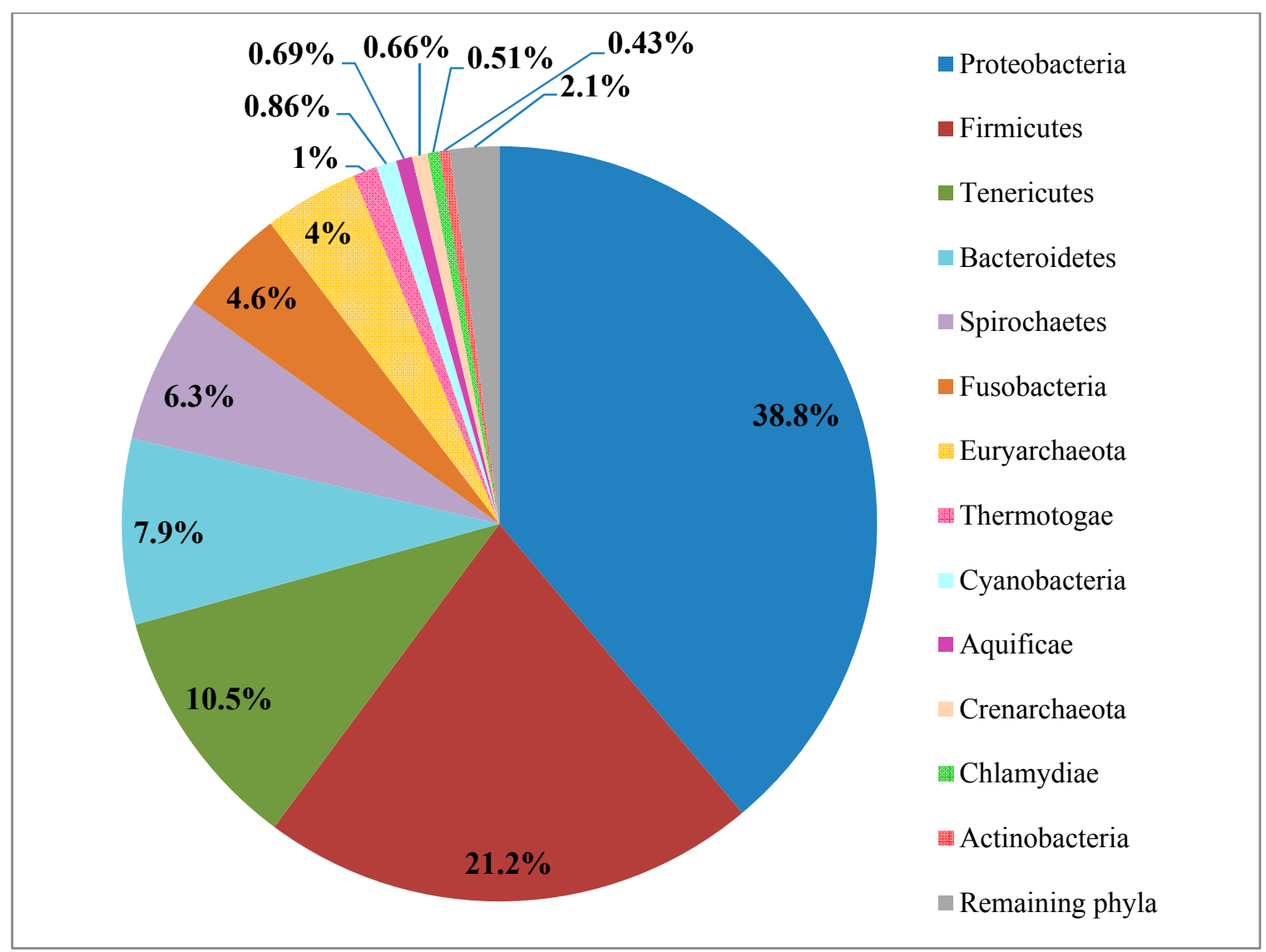

To our current knowledge only a few microbiomes associated with seaweed or sea grass eating animals have been analyzed in metagenomic projects (Figure 3). Previous metagenomic studies investigated the microbial assemblage from the sea slug Elysia chlorotica [27], its relative Elysia rufescens [28], the marine iguana Amblyrhynchus cristatus [6] and the sea cow Dugong dugon [7]. Of these, only the two last metagenomes could be directly related to the diet of their animal hosts as metagenomic data was generated based on microbial DNA extracted from faeces of marine iguana and sea cow, respectively. In the case of both molluscs, metagenomic analysis of microbial communities revealed main groups of microbes associated with the entire body of the slugs as well as the mucus from Elysia rufescens. Based on this data and literature concerning the industrial potential of marine microbes we characterized the microbiome from $P$. pellucida's gastrointestinal tract focusing on three bacterial phyla: Proteobacteria, Firmicutes and Bacteroidetes (Figure 4A-C). These three phyla were investigated due to their significant abundance within the sample as well as the biotechnological potential that certain of their members could present and which therefore deserves to be explored in further research. 
Figure 3. Comparison of the Phylum level microbiome associated with P. pellucida gastrointestinal tract to those associated with other seaweed and sea grass grazers: ML-Marine Limpet P. pellucida; MSS (E.c)-Marine Sea Slug Elysia chlorotica; MSS (E.r)-Marine Sea Slug Elysia rufescens; MI-Marine Iguana Amblyrhynchus cristatus; SC-Sea Cow Dugong dugon.

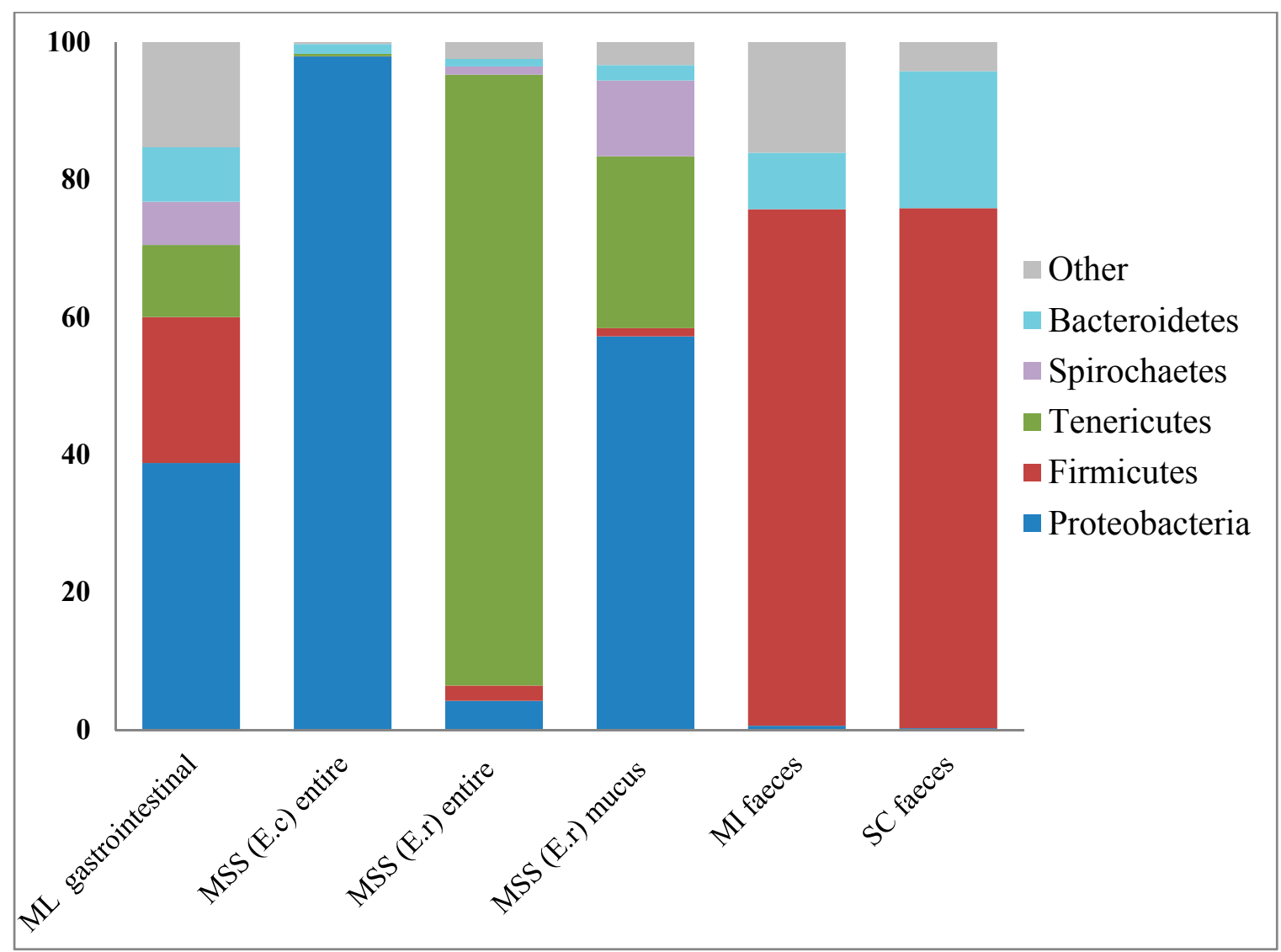

Figure 4. Phylogenomic class level characterization within the phyla (A) Proteobacteria (B) Firmicutes and (C) Bacteroidetes (from the digestive tract of $P$. pellucida).
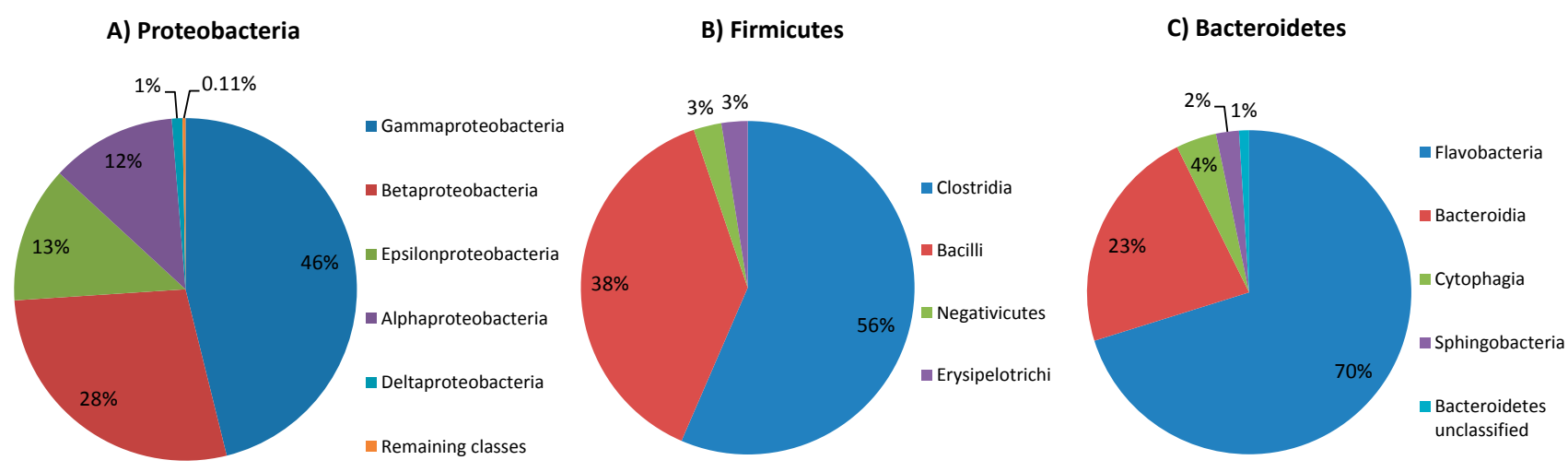


\subsection{Proteobacteria}

The taxonomic analysis of metagenomic reads indicated Proteobacteria as the most abundant phylum in the digestive tract of $P$. pellucida (Figure 2). This phylum is currently the largest and the most complex phenotypically bacterial lineage, which usually dominates prokaryotic taxa in samples derived from marine environments and is very often associated with marine animals including sea snails (Figure 3), fish, shrimps and sponges [19,27-30]. Due to the huge biodiversity, members of this phylum have been shown to display various functions towards the specific marine ecosystem where they are found. Many of those features such as production of powerful enzymes, synthesis of antimicrobial compounds or antifouling agents have been identified [8,31], but much more is yet to be discovered.

MetaPhlAn analysis indicated that the majority of Proteobacteria harbored by the limpet was composed of the class Gammaproteobacteria as well as four less abundant subdivisions: Betaproteobacteria, Epsilonoproteobacteria, Alphaproteobacteria and Deltaproteobacteria (Figure 4A). The majority of shotgun reads within phylum Proteobacteria were assigned to the group of uncultivated endosymbionts with reduced genomes (Table 1) such as those belonging to the genus "Candidatus Carsonella" [32] (class Gammaproteobacteria) and "Candidatus Zinderia" [33] (class Betaproteobacteria). Being vertically transferred with eggs from one host generation to another these bacteria are known to live inside bacteriocytes providing their hosts with essential compounds in exchange for nutrients and protection [34]. The large number of metagenomic reads identified as belonging to these microbes could be explained by the fact that metagenomic DNA was isolated from $P$. pellucida when the limpets were in their reproductive cycle. Due to the small size and proximity of organs composing the visceral mass of $P$. pellucida, dissected gastrointestinal material was most probably contaminated with symbiotic bacteria residing in developing eggs. Related microbes to these, e.g., "Candidatus Endobugula sertula", found in larvae of marine bryozoan Bugula neritina [35], have recently been identified as a likely source of bryostatins. These are natural polyketide compounds providing defense against predators and have been extensively tested for anticancer activity [36]. In its life cycle $P$. pellucida also undergoes a planktonic larvae stage [3], possibly with a similar chemical defense protection mechanism. Thus it is possible that genes for synthesizing novel polyketide toxins could be found in abundant populations of related intracellular symbionts harbored by the limpet.

Another group of Proteobacteria, distinguished based on MetaPhlAn analysis, was represented by bacteria that are known to display chemolithotrophic properties (Table 1). Analysis predictions identified sequences for microbes in the Betaproteobacteria class assigned to the genus Nitrosomonas. This genus is known to include ammonia-oxidizing bacteria. Another class, Epsilonoproteobacteria included bacteria belonging to sulphur and nitrate reducing genera such as Nitratiruptor and Caminibacter, whereas class Deltaproteobacteria was dominated by sulphate-reducing microbes from the genera Desulfovibrio and Desulfotalea. Interestingly, certain members of these genera are known from the literature to be strictly thermophilic microbes associated with extreme aquatic environments, e.g., hydrothermal vents as well as the invertebrates thriving there [37-39], and their presence in association with the cold water mollusc Patella pellucida appears enigmatic. Some of these bacteria may be displaying an ability for efficient neutralization of toxic metal ions (e.g., Desulfovibrio vulgaris) [40] or the degradation of a variety of halogenated organic compounds 
(e.g., Nitrosomonas europaea) [41]. These microbes and their abilities could be of special interest for industrial applications such as bioremediation of oil-polluted marine environments or contaminated soils.

Table 1. Categorization and predicted function of members of the phylum Proteobacteria.

\begin{tabular}{|c|c|c|c|c|c|}
\hline Class & $\begin{array}{c}\text { The Most } \\
\text { Abundant Order } \\
\text { (\% of Class) }\end{array}$ & $\begin{array}{c}\text { The Most } \\
\text { Abundant Family } \\
\text { (\% of Order) }\end{array}$ & $\begin{array}{c}\text { The Most Abundant } \\
\text { Genus/Species }\end{array}$ & $\begin{array}{c}\text { Functional } \\
\text { Role/Habitat }\end{array}$ & Ref. \\
\hline \multirow{3}{*}{ Gammaproteobacteria } & $\begin{array}{c}\text { Enterobacteriales } \\
(76.34)\end{array}$ & $\begin{array}{c}\text { Enterobacteriaceae } \\
(100)\end{array}$ & $\begin{array}{c}\text { “Candidatus } \\
\text { Carsonella"/ } \\
\text { “Candidatus } \\
\text { Carsonella rudii" }\end{array}$ & $\begin{array}{c}\text { nutrients } \\
\text { supply/obligate } \\
\text { endosymbiont } \\
\text { of psyllids } \\
\end{array}$ & {$[32,34]$} \\
\hline & $\begin{array}{c}\text { Pasteurellales } \\
(4.84)\end{array}$ & $\begin{array}{c}\text { Pasteurellaceae } \\
(100)\end{array}$ & $\begin{array}{c}\text { Haemophilus/ } \\
\text { Haemophilus influenzae }\end{array}$ & \multirow{2}{*}{$\begin{array}{l}\text { pathogenic/human } \\
\text { and animals }\end{array}$} & {$[42]$} \\
\hline & $\begin{array}{c}\text { Thiotrichales } \\
\text { (3.45) }\end{array}$ & $\begin{array}{c}\text { Francisellaceae } \\
(87.09)\end{array}$ & $\begin{array}{c}\text { Francisellal } \\
\text { Francisella tularenisis }\end{array}$ & & [43] \\
\hline \multirow{3}{*}{ Betaproteobacteria } & $\begin{array}{c}\text { Burkholderiales } \\
\quad \text { (94.65) }\end{array}$ & $\begin{array}{c}\text { Oxalobacteraceae } \\
(98.63)\end{array}$ & $\begin{array}{l}\text { "Candidatus Zinderia"/ } \\
\text { "Candidatus Zinderia" } \\
\text { (unclassified) }\end{array}$ & $\begin{array}{c}\text { nutrients } \\
\text { supply/obligate } \\
\text { endosymbiont } \\
\text { of spittlebug }\end{array}$ & {$[33]$} \\
\hline & $\begin{array}{c}\text { Neisseriales } \\
(4.7)\end{array}$ & $\begin{array}{c}\text { Neisseriaceae } \\
(100)\end{array}$ & $\begin{array}{c}\text { Neisserial } \\
\text { Neisseria meningitides }\end{array}$ & $\begin{array}{c}\text { pathogenic/human } \\
\text { origin }\end{array}$ & {$[44]$} \\
\hline & $\begin{array}{c}\text { Nitrosomonadales } \\
(0.27)\end{array}$ & $\begin{array}{c}\text { Nitrosomonadaceae } \\
(100)\end{array}$ & $\begin{array}{c}\text { Nitrosomonas/ } \\
\text { Nitrosomonas europea }\end{array}$ & $\begin{array}{c}\text { ammonia } \\
\text { oxidation/sewage } \\
\text { plants disposal; } \\
\text { water; soil }\end{array}$ & {$[41,45]$} \\
\hline \multirow{3}{*}{ Epsilonoproteobacteria } & $\begin{array}{c}\text { Campylobacterales } \\
\text { (81.6) }\end{array}$ & $\begin{array}{c}\text { Campylobacteraceae } \\
(64.21)\end{array}$ & $\begin{array}{c}\text { Campylobacterl } \\
\text { Campylobacter lari }\end{array}$ & $\begin{array}{c}\text { pathogenic/gastrointest } \\
\text { inal of human } \\
\text { and animals }\end{array}$ & {$[46]$} \\
\hline & $\begin{array}{c}\text { Nautiliales } \\
\quad(16.6)\end{array}$ & $\begin{array}{l}\text { Nautilaceae } \\
\quad(100)\end{array}$ & $\begin{array}{l}\text { Caminibacter/ } \\
\text { Caminibacter } \\
\text { mediatlanticus }\end{array}$ & \multirow{2}{*}{$\begin{array}{c}\text { nitrate and sulphur } \\
\text { reduction/deep-sea } \\
\text { hydrothermal systems }\end{array}$} & [37] \\
\hline & $\begin{array}{c}\text { Epsilonoproteo- } \\
\text { bacteria } \\
\text { (unclassified) } \\
(1.72) \\
\end{array}$ & $\begin{array}{c}\text { Nitratiruptor } \\
\quad(62.5)\end{array}$ & $\begin{array}{l}\text { Nitratiruptor/ } \\
\text { Nitratiruptor } \\
\text { (unclassified) }\end{array}$ & & [38] \\
\hline \multirow{3}{*}{ Alphaproteobacteria } & $\begin{array}{c}\text { Rickettsiales } \\
(76.67) \\
\end{array}$ & $\begin{array}{c}\text { Rickettsiaceae } \\
(60.5)\end{array}$ & $\begin{array}{c}\text { Rickettsial } \\
\text { Rickettsia bellii }\end{array}$ & $\begin{array}{c}\text { pathogenic/ } \\
\text { human and animals }\end{array}$ & {$[47]$} \\
\hline & Rhizobiales & $\begin{array}{c}\text { Bartonellaceae } \\
(45.05) \\
\end{array}$ & $\begin{array}{c}\text { Bartonellal } \\
\text { Bartonella henselae }\end{array}$ & \multirow{2}{*}{$\begin{array}{c}\text { pathogenic/ } \\
\text { human and animals }\end{array}$} & {$[48]$} \\
\hline & (19.65) & $\begin{array}{c}\text { Brucellaceae } \\
(38.46)\end{array}$ & $\begin{array}{c}\text { Brucellal } \\
\text { Brucella abortus }\end{array}$ & & [49] \\
\hline \multirow{3}{*}{ Deltaproteobacteria } & $\begin{array}{c}\text { Desulfovibrionales } \\
\text { (41.02) }\end{array}$ & $\begin{array}{c}\text { Desulfovibrionaceae } \\
(87.5)\end{array}$ & $\begin{array}{c}\text { Desulfovibriol } \\
\text { Desulfovibrio } \\
\text { magneticus }\end{array}$ & \multirow{2}{*}{$\begin{array}{c}\text { sulphate- } \\
\text { reduction/marine } \\
\text { sediments; } \\
\text { gastrointestinal of } \\
\text { human and animals }\end{array}$} & {$[50,51]$} \\
\hline & $\begin{array}{c}\text { Desulfobacterales } \\
(17.94)\end{array}$ & $\begin{array}{c}\text { Desulfobulbaceae } \\
(42.85)\end{array}$ & $\begin{array}{c}\text { Desulfotalea/Desulfotal } \\
\text { ea psychrophila }\end{array}$ & & {$[52]$} \\
\hline & $\begin{array}{c}\text { Bdellovibrionales } \\
\text { (17.94) }\end{array}$ & $\begin{array}{c}\text { Bacteriovoraceae } \\
(85.7)\end{array}$ & $\begin{array}{c}\text { Bacteriovorax/ } \\
\text { Bacteriovorax marinus }\end{array}$ & $\begin{array}{c}\text { predatory/marine } \\
\text { environment }\end{array}$ & {$[53]$} \\
\hline
\end{tabular}


Proteobacteria associated with the gastrointestinal tract of $P$. pellucida were also comprised of many species belonging to genera associated with pathogens of marine animals and plants and known to cause foodborne human disease. Of these, bacteria from genera Haemophilus and Francisella were identified in the Gammaproteboacteria class; members of Neisseria were found in the Betaproteobacteria class; species belonging to the genus Campylobacter in the Epsilonoproteobacteria class and species from genera: Rickettsia, Bartonella as well as Brucella in the Alphaproteobacteria class.

\subsection{Firmicutes}

Bacteria from the phylum Firmicutes were identified by MetaPhlAn metagenomic analysis as the second largest lineage in the investigated microbiome after Proteobacteria (Figure 2). Firmicutes are a group of mostly gram positive, spore forming bacteria, often anaerobic and as such are associated with environments of oxygen deficit. Microbes belonging to this phylum commonly inhabit marine ecosystems, where they can be found free living in sea water, marine sediments and as symbionts or parasites hosted by marine animals [54]. Firmicutes are a natural gut microbiota component of saltwater animals including marine iguanas with an exclusively algal diet [6] and sea grass-grazing sea cows [7]. In metagenomic studies on these animals they were found as the predominant phylum in faecal samples (Figure 3). Being involved in complex enzymatic processes of recalcitrant polysaccharide degradation and fermentation as well as displaying capabilities to survive a range of environmental conditions; some members of Firmicutes are currently among the most broadly used candidates for various biorefining processes [55-58]. Our metagenomic analysis revealed that Firmicutes derived from the gastrointestinal system of limpets were overrepresented by two main classes: Clostridia and Bacilli, whereas the rest of the phylum constituted two minor subdivisions: Negavicutes and Erysipelotrichi (Figure 4B). Clostridiales and Thermoanaerobacterales identified in the Clostridia class, as well as Bacillales and Lactobacilliales assigned to the Bacilli class (Table 2), represented genera and species that are broadly associated with applications in all the key metabolic stages of the biorefinery processes: polymer hydrolysis, sugar fermentation and anaerobic digestion. For example specific species of the genus Bacillus, found in the analysed metagenome could have similar properties to recently reported strains of Bacillus used for initial biological saccharification and fermentation of seaweed $[59,60]$. Although not usually associated with high salt concentration environments, marine bacteria from the genus Lactobacillus are also of growing biotechnological interest in the functional food sector due to their potential capacity to produce lactic acid from seaweed [61,62]. 
Table 2. Categorization and predicted function of members of the phylum Firmicutes.

\begin{tabular}{|c|c|c|c|c|c|}
\hline Class & $\begin{array}{c}\text { The Most } \\
\text { Abundant Order } \\
\text { (\% of Class) } \\
\end{array}$ & $\begin{array}{c}\text { The Most } \\
\text { Abundant Family } \\
\text { (\% of Order) }\end{array}$ & $\begin{array}{c}\text { The Most } \\
\text { Abundant } \\
\text { Genus/Species }\end{array}$ & Functional Role/Habitat & Ref. \\
\hline \multirow{4}{*}{ Clostridia } & \multirow{2}{*}{$\begin{array}{c}\text { Clostridiales } \\
\text { (72.62) }\end{array}$} & $\begin{array}{c}\text { Clostridiaceae } \\
\text { (49.71) }\end{array}$ & $\begin{array}{l}\text { Clostridium/ } \\
\text { Clostridium } \\
\text { butyricum }\end{array}$ & $\begin{array}{c}\text { polysaccharides degradation } \\
\text { and fermentation; } \\
\text { pathogenic/gastrointestinal } \\
\text { of human and animals; } \\
\text { feaces; soil; water }\end{array}$ & {$[54,63]$} \\
\hline & & $\begin{array}{c}\text { Clostridiales } \\
\text { Family XI } \\
\text { Incertae sedis } \\
\quad(47.23) \\
\end{array}$ & $\begin{array}{l}\text { Anaerococcus/ } \\
\text { Anaerococcus } \\
\text { vaginalis }\end{array}$ & $\begin{array}{l}\text { polysaccharides degradation } \\
\text { and fermentation/clinical } \\
\text { specimens of human origin }\end{array}$ & {$[64]$} \\
\hline & \multirow[t]{2}{*}{$\begin{array}{l}\text { Thermoanaerobacterales } \\
\text { (22.71) }\end{array}$} & $\begin{array}{l}\text { Thermoanaero- } \\
\text { bacterales } \\
\text { Familly III } \\
\text { Incertae sedis } \\
\text { (53.84) }\end{array}$ & $\begin{array}{l}\text { Caldicellulosiruptor/ } \\
\text { Caldicellulosiruptor } \\
\text { kronotskyensis }\end{array}$ & \multirow{2}{*}{$\begin{array}{l}\text { polysaccharides degradation } \\
\text { and fermentation/hot } \\
\text { springs; deep-sea } \\
\text { hydrothermal systems }\end{array}$} & [65] \\
\hline & & $\begin{array}{c}\text { Thermoanaero- } \\
\text { bacteraceae } \\
\text { (45.42) }\end{array}$ & $\begin{array}{c}\text { Thermoanaerobacter/ } \\
\text { Thermoanaerobacter } \\
\text { ethanolicus }\end{array}$ & & [66] \\
\hline \multirow{4}{*}{ Bacilli } & \multirow{2}{*}{$\begin{array}{l}\text { Lactobacillales } \\
\text { (51.96) }\end{array}$} & $\begin{array}{c}\text { Streptococcaceae } \\
(40.89)\end{array}$ & $\begin{array}{c}\text { Streptococcus/ } \\
\text { Streptococcus bovis }\end{array}$ & $\begin{array}{c}\text { pathogenic/clinical } \\
\text { specimens of human and } \\
\text { animals origin }\end{array}$ & {$[67,68]$} \\
\hline & & $\begin{array}{c}\text { Lactobacillaceae } \\
(34.51)\end{array}$ & $\begin{array}{c}\text { Lactobacillus/ } \\
\text { Lactobacillus iners }\end{array}$ & $\begin{array}{c}\text { polysaccharides } \\
\text { fermentation/gastrointestinal } \\
\text { of human and animals; } \\
\text { water; soil }\end{array}$ & {$[61,62]$} \\
\hline & \multirow{2}{*}{$\begin{array}{c}\text { Bacillales } \\
(48.03)\end{array}$} & $\begin{array}{c}\text { Bacillaceae } \\
(36.82)\end{array}$ & $\begin{array}{c}\text { Bacillus/Bacillus } \\
\text { thuringiensis }\end{array}$ & $\begin{array}{l}\text { polysaccharides degradation } \\
\text { and fermentation/ } \\
\text { gastrointestinal of human } \\
\text { and animals; water; soil }\end{array}$ & {$[69]$} \\
\hline & & $\begin{array}{c}\text { Staphylococcaceae } \\
(34.78)\end{array}$ & $\begin{array}{l}\text { Staphylococcus/ } \\
\text { Staphylococcus } \\
\text { hominis }\end{array}$ & $\begin{array}{c}\text { polysaccharides } \\
\text { fermentation; } \\
\text { pathogenic/water; soil; } \\
\text { clinical specimens of human } \\
\text { and animals origin } \\
\end{array}$ & {$[70,71]$} \\
\hline Negativivicutes & $\begin{array}{c}\text { Selenomonadales } \\
(100)\end{array}$ & $\begin{array}{l}\text { Veillonellaceae } \\
\qquad(96.49)\end{array}$ & $\begin{array}{c}\text { Dialister/Dialister } \\
\text { microaerophilus }\end{array}$ & $\begin{array}{l}\text { fermentation/water; soil; } \\
\text { gastrointestinal of human } \\
\text { and animals; clinical } \\
\text { specimens of human origin }\end{array}$ & [72] \\
\hline Erisipelotrichi & $\begin{array}{c}\text { Erisipelotrichales } \\
\text { (100) }\end{array}$ & $\begin{array}{l}\text { Erisipelotrichaceae } \\
\qquad(100)\end{array}$ & $\begin{array}{c}\text { Coprobacillus/Copro } \\
\text { bacillus sp. } \\
\text { (unclassified) }\end{array}$ & $\begin{array}{l}\text { fermentation/gastrointestinal } \\
\text { of human and animals origin }\end{array}$ & [73] \\
\hline
\end{tabular}




\subsection{Bacteroidetes}

The third relatively abundant and biotechnologically important phylum within the prokaryotic assemblage of the marine limpet digestive tract was the Bacteroidetes (Figure 2). In a similar manner to the Firmicutes, members of this group are commonly found in marine biotopes and the intestines of marine animals. Based on the findings of previous studies, Bacteroidetes are often associated with microbial populations residing on seaweed [74] as well as in the guts of animals grazing on seaweed [6] or sea grass [7] (Figure 3), where one of their main functions is the degradation of high molecular weight compounds [51]. Bacteroidetes in marine environments are well equipped with specific mechanisms (such as adhesion proteins and genes for gliding motility) [75], allowing them to attach to the surface of seaweed, plankton or various biofilms. These features help them to get better access to the decomposed organic matter that they generate through the secretion of a range of extracellular enzymes. Due to the high plasticity of the Bacteroidetes genomes, involving various genetic rearrangements, gene duplications and lateral gene transfer, these bacteria can easily adapt to distinct ecological niches [76]. These facts can suggest that free-living Bacteroidetes consumed by $P$. pellucida could continuously contribute to the degradation of brown algae polysaccharides in the gastrointestinal tract of the limpets.

According to MetaPhlAn the majority of Bacteroidetes reads were assigned to the class Flavobacteriia followed by the class Bacteroidia, Cytophagia, Sphingobacteriia and unclassified Bacteroidetes (Figure 4C). Most of the bacteria distributed among these subdivisions were identified as belonging to the genera including bacteria of strictly saccharolytic profiles, e.g., Cellulophaga, Bacteroides or Cytophaga (Table 3). The recent sequencing of genomes of their members confirms that they are encoding a plethora of enzymes active towards very specific substrates. For example, examination of the Cellulophaga lytica type strain (LIM-21) genome revealed the existence of genes involved in degradation of cellulose, alginate and sulphated fucans [77]. The Bacteroides thetaiotaomicron genome was reported to encode genes catalyzing cellulose, starch, xylose, laminarin, alginate, and chitin breakdown [78], whereas the genome of Cytophaga hutchinsonii was predicted to encode cellulose, xylan and alginate depolymerizing enzymes [79]. Bacteroidetes also contained a large proportion of bacteria belonging to the genera known as obligate endosymbionts, e.g., "Candidatus Sulcia", Blattabacterium and "Candidatus Amoebophilus" (Table 3), which similarly to those found in the phylum Proteobacteria are characteristic for their extremely reduced genomes and are predicted to provide essential nutrients to the host. 
Table 3. Categorization and predicted function of members of the phylum Bacteroidetes.

\begin{tabular}{|c|c|c|c|c|c|}
\hline Class & $\begin{array}{c}\text { The Most } \\
\text { Abundant Order } \\
\text { (\% of Class) } \\
\end{array}$ & $\begin{array}{c}\text { The Most } \\
\text { Abundant Family } \\
\text { (\% of Order) } \\
\end{array}$ & $\begin{array}{c}\text { The Most } \\
\text { Abundant } \\
\text { Genera/Species }\end{array}$ & Functional Role/Habitat & Ref. \\
\hline \multirow{3}{*}{ Flavobacteriia } & \multirow{3}{*}{$\begin{array}{l}\text { Flavobacteriales } \\
\qquad(100)\end{array}$} & $\begin{array}{c}\text { Flavobacteriales } \\
\text { (unclassified) } \\
\text { (54) }\end{array}$ & $\begin{array}{l}\text { "Candidatus Sulcia"/ } \\
\text { "Candidatus Sulcia } \\
\text { muelleri” }\end{array}$ & $\begin{array}{c}\text { nutrients supply/obligate } \\
\text { endosymbiont of } \\
\text { sharpshooters } \\
\end{array}$ & {$[33]$} \\
\hline & & $\begin{array}{c}\text { Flavobacteriaceae } \\
\qquad(36)\end{array}$ & $\begin{array}{c}\text { Cellulophaga/ } \\
\text { Cellulophaga lytica }\end{array}$ & $\begin{array}{c}\text { polysaccharides } \\
\text { degradation/diatoms; } \\
\text { algae; seawater } \\
\end{array}$ & {$[77]$} \\
\hline & & $\begin{array}{c}\text { Blattabacteriaceae } \\
\text { (10) }\end{array}$ & $\begin{array}{c}\text { Blattabacterium/ } \\
\text { Blattabacterium sp. } \\
\text { (unclassified) }\end{array}$ & $\begin{array}{c}\text { nutrients supply/obligate } \\
\text { endosymbiont of cockroaches } \\
\text { and termites }\end{array}$ & {$[80]$} \\
\hline \multirow{3}{*}{ Bacteroidia } & \multirow{3}{*}{$\begin{array}{c}\text { Bacteroidales } \\
\text { (100) }\end{array}$} & $\begin{array}{c}\text { Bacteroidaceae } \\
\text { (52) }\end{array}$ & $\begin{array}{c}\text { Bacteroides/ } \\
\text { Bacteroides } \\
\text { Xylanisolvens }\end{array}$ & $\begin{array}{l}\text { polysaccharides degradation } \\
\text { and fermentation/human and } \\
\text { animals gastrointestinal }\end{array}$ & {$[78,81]$} \\
\hline & & $\begin{array}{l}\text { Prevotellaceae } \\
\text { (24) }\end{array}$ & $\begin{array}{c}\text { Prevotellal } \\
\text { Prevotella amnii }\end{array}$ & $\begin{array}{l}\text { polysaccharides degradation } \\
\text { and fermentation/human and } \\
\text { animals gastrointestinal }\end{array}$ & {$[51,82]$} \\
\hline & & $\begin{array}{c}\text { Porphyromonadaceae } \\
\text { (14) }\end{array}$ & $\begin{array}{c}\text { Paludibacterl } \\
\text { Paludibacter } \\
\text { propionicigenes } \\
\end{array}$ & $\begin{array}{l}\text { polysaccharides } \\
\text { fermentation/plant residue }\end{array}$ & {$[83]$} \\
\hline \multirow{3}{*}{ Cytophagia } & \multirow{3}{*}{$\begin{array}{c}\text { Cytophagales } \\
\text { (100) }\end{array}$} & $\begin{array}{c}\text { Cytophagaceae } \\
(54)\end{array}$ & $\begin{array}{c}\text { Cytophaga/Cytophaga } \\
\text { hutchinsonii }\end{array}$ & $\begin{array}{l}\text { polysaccharides } \\
\text { degradation/soil }\end{array}$ & {$[79]$} \\
\hline & & $\begin{array}{c}\text { Flammeovirgaceae } \\
(26)\end{array}$ & $\begin{array}{c}\text { Marivirgal } \\
\text { Marivirga tractuosa }\end{array}$ & $\begin{array}{c}\text { polysaccharides } \\
\text { degradation/water; mud; sand }\end{array}$ & {$[84]$} \\
\hline & & $\begin{array}{c}\text { Cyclobacteriaceae } \\
\text { (24) }\end{array}$ & $\begin{array}{c}\text { Algoriphagus/ } \\
\text { Algoriphagus } \\
\text { unclassified } \\
\end{array}$ & $\begin{array}{c}\text { polysaccharides } \\
\text { degradation/marine } \\
\text { solar saltern } \\
\end{array}$ & {$[85]$} \\
\hline \multirow{4}{*}{ Sphingobacteriia } & \multirow{4}{*}{$\begin{array}{c}\text { Sphingobacteriales } \\
(100)\end{array}$} & \multirow{3}{*}{$\begin{array}{c}\text { Sphingobacteriaceae } \\
(92)\end{array}$} & $\begin{array}{c}\text { Pedobacterl } \\
\text { Pedobacter saltans }\end{array}$ & $\begin{array}{l}\text { sulphates degradation/soil; } \\
\text { water; fish }\end{array}$ & {$[86]$} \\
\hline & & & $\begin{array}{c}\text { Sphingobacterium/ } \\
\text { Sphingobacterium } \\
\text { spiritivorum }\end{array}$ & $\begin{array}{c}\text { synthesis of } \\
\text { antimicrobials/specimens of } \\
\text { human origin } \\
\end{array}$ & {$[87]$} \\
\hline & & & $\begin{array}{c}\text { Mucilaginibacter/ } \\
\text { Mucilaginibacter } \\
\text { paludis }\end{array}$ & $\begin{array}{c}\text { polysaccharides } \\
\text { degradation/sphagnum } \\
\text { peat bog }\end{array}$ & {$[88]$} \\
\hline & & $\begin{array}{c}\text { Chitinophagacea } \\
\text { (7) }\end{array}$ & $\begin{array}{c}\text { Chitinophagal } \\
\text { Chitinophaga pinensis }\end{array}$ & $\begin{array}{l}\text { polysaccharides } \\
\text { degradation/soil }\end{array}$ & {$[89]$} \\
\hline $\begin{array}{c}\text { Bacteroidetes } \\
\text { unclasified }\end{array}$ & $\begin{array}{c}\text { Bacteroidetes } \\
\text { (unclassified) } \\
\text { (100) }\end{array}$ & $\begin{array}{c}\text { Bacteroidetes } \\
\text { (unclassified) } \\
\text { (100) }\end{array}$ & $\begin{array}{c}\text { "Candidatus } \\
\text { Amoebophilus"/ } \\
\text { "Candidatus } \\
\text { Amoebophilus" } \\
\text { (unclassified) }\end{array}$ & $\begin{array}{l}\text { nutrients supply/obligate } \\
\text { endosymbiont of amoeba }\end{array}$ & {$[76]$} \\
\hline
\end{tabular}




\subsection{Remaining Phyla}

The remaining phyla within the analyzed metagenome were represented by two archaeal and eight bacterial taxons (Figure 2). Archaea identified in the gastrointestinal tract of limpets belonged to two phylogenetic lineages: Euryarcheota and Crenarcheota, encompassing respectively $4 \%$ and $0.66 \%$ of the whole microbiome. Members of both phyla were reported to be found in salt water ecosystems and are common inhabitants of certain marine animals such as sea cucumbers, sponges and fish [90-92]. They include extremophilic halophiles and thermophiles which produce methane (Euryarcheota) and are capable of ammonia oxidation (Crenarcheota). Of the remaining metagenomic bacteria, $P$. pellucida harbored a relatively abundant population of Tenericutes (10.5\%), and Spirochaetes (6.3\%), which were both previously found to be associated with the metagenome of marine sea slugs [27,28] (Figure 3). Microbes representing these phyla are primarily known as pathogens in a wide range of mammalian hosts $[93,94]$. Although there is a general lack of information on the function of these bacteria towards inhabited marine and freshwater animals, recent studies suggest that their members are providing benefits rather than causing detriment to their hosts which include snails, oysters and crabs [95,96]. The Fusobacteria phylum was found to compose $4.6 \%$ of $P$. pellucida's microbiome and is another lineage of bacteria. This phylum has primarily been studied in relation to human and higher animals' diseases [97], and their role in association with animals of aquatic origin is poorly understood [98]. Phyla which did not exceed $1 \%$ of total abundance were identified as: Thermotogae, Cyanobacteria, Aquificae, Chlamydiae, and Actinobacteria, among others. In spite of the low abundance in the metagenome, members of these microbial groups could play important roles within the blue-rayed limpet. For example, bacteria from the phylum Thermotogae together with the closely branched phylum of Aquificae could benefit the host by degrading dietary complex carbohydrates [99], members of the phylum Actinobacteria could provide defense against pathogens [100], and symbiotic Cyanobacteria might fix and provide nitrogen to the limpet [101].

\section{Materials and Methods}

\subsection{P. pellucida Collection and Maintenance}

Over 100 P. pellucida limpets were collected from the rocky seashore at Aberystwyth $\left(52.4140^{\circ} \mathrm{N}\right.$, $4.0810^{\circ} \mathrm{W}$ ), Ceredigion, Wales in late November 2012, when individuals were approximately $7 \mathrm{~mm}$ in length. Within one hour following collection, limpets were transferred to a glass tank filled with water of 3.2\%-3.4\% salinity. The tank was equipped with 2 sets of lights (AquaRay AquaBeam 600Ultra, Tropical Marine Centre, Bristol, UK) coupled to the timer (AquaRay Controller, Tropical Marine Centre) synchronised with the naturally occurring Mid-Wales (UK) light/dark cycle. The tank was connected to the Salt Water Filtration System (TMC System5000, Tropical Marine Center) supplying oxygen and providing re-circulated, temperature controlled, mechanically and biologically filtered, UV-sterilised seawater. A single water pump (SEIO Super Flow M250 Pump, TAAM, Camarillo, CA, USA) placed in the tank provided additional water movement. Each of the collected $P$. pellucida limpets was attached to the surface of $L$. digitata, submerged in the tank and left for one month to graze and grow. Maintenance of the limpets on L. digitata in the tank prior to dissection was to reduce transient bacteria, to ensure the limpets were large enough for accurate dissection and to 
make sure that they are actively grazing. Additionally, being maintained for one month prior to dissection ensured that if any bacteria essential for macroalgae breakdown were being lost from the limpets, then P. pellucida would not survive under these conditions.

\subsection{Indirect Extraction of Metagenomic DNA}

All the following extraction steps of indirect extraction of prokaryotic DNA from the P. pellucida digestive tract were conducted on ice unless otherwise stated. Sixty limpets were placed on sterile petri dishes at room temperature and anesthetized by flooding the plates with sterile, isotonic (7.2\%) magnesium chloride solution [102]. After 15 min limpets were transferred to new, sterile petri dishes and sprayed with $70 \%$ ethanol to remove surface-contaminating microbes. Limpets were rinsed with distilled water and the intestines were then aseptically dissected. The dissected material was collected in $2 \mathrm{~mL}$ microcentrifuge tubes floating in liquid nitrogen, $1 \mathrm{~mL}$ of ice cold $50 \mathrm{mM}$ potassium phosphate buffer at $\mathrm{pH} 7.5$ was added, vortexed and homogenized for $2 \mathrm{~s}$ using homogenizer (T10 basic ULTRA-TURRAX, IKA-Werke GmbH \& Co. KG, Staufen, Germany). Each sample was then centrifuged at $60 \times \mathrm{g}$ for $30 \mathrm{~s}$. One milliliter of supernatant from each sample was decanted into a new $2 \mathrm{~mL}$ microcentrifuge tube, passed through 90, 50 and subsequently $10 \mu \mathrm{m}$ mesh cloths (Cadisch MDA Ltd., London, UK) and collected into new $2 \mathrm{~mL}$ microcentrifuge tubes. The fraction obtained was filtered again using a sterile $0.8 \mu \mathrm{m}$ syringe filter (Gilson Scientific Ltd., Luton, UK) and collected into a $2 \mathrm{~mL}$ microcentrifuge tube. The final filtrate was centrifuged at $9600 \times \mathrm{g}$ for $5 \mathrm{~min}$ to concentrate the microbial cells as a pellet. The supernatant was discarded and the pellet resuspended with $978 \mu \mathrm{L}$ of $50 \mathrm{mM}$ potassium phosphate buffer at $\mathrm{pH}$ 7.5. The DNA of this pellet was extracted using a FastDNA $^{\circledR}$ Spin Kit for Soil (Qbiogene, Cambridge, UK), according to the manufacturer's protocol.

\subsection{Metagenomic DNA Sequencing, Assembling and Taxonomic Profiling of the Corresponding Microbial Community}

Indirectly extracted DNA was used to create an Illumina paired-end library with an average insert size of 360 base pairs (bp) according to the manufacturer's instructions (TruSeq DNA LT Paired-End Sample Prep Kit, Rev. E, Illumina, Ltd., Essex, UK). The library was sequenced at $2 \times 101$ base pairs (bp) using the Illumina HiSeq2500 platform at the IBERS Aberystwyth Translational Genomics Facility (Aberystwyth, UK), according to standard procedures. The final sequenced library consisted of 398 million reads. The reads were cleaned using fastq-mcf from ea-utils [103], which removed adaptor sequences, low quality reads (a minimum quality score of 20 was required), and short reads $<31 \mathrm{bp}$. The reads were then trimmed to remove the first $15 \mathrm{bp}$. This resulted in 391 million reads mostly in the size range of $78-84 \mathrm{bp}$, giving a total of 16.458 billion bp. These relatively short reads were additionally contaminated with host-derived sequences and so were not sufficient for reliable functional analysis. However they could be successfully used in taxonomic analysis of the microbiome. Taxonomic profiling of metagenomic DNA was performed using the MetaPhlAn (Metagenomic Phylogenetic Analysis) tool, which uses more than 115,000 prokaryotic clade-specific marker genes collected from over 1200 species [25]. It has been widely and successfully used in human microbiome studies where it has been proven to be capable of identifying taxonomies at the species level by aligning metagenomics reads to the database of marker genes in order to estimate the relative 
abundance of each microbial group [26]. Here we used MetaPhlAn with its default options i.e., by using the bowtie short read aligner to map the reads against the database of marker genes. The advantage of using MetaPhlAn over de novo assembly approaches is that MetaPhlAn uses all reads available in the sample and can therefore identify species present at low levels, whereas de novo assembly approaches often struggle to generate contigs from these less abundant species with the result that they are often missed by downstream analyses [25]. In addition, MetaPhlAn has previously been positively evaluated on noisy shotgun reads derived from environmental samples with limited coverage of reference genomes. These features are relevant to this study because of contamination from the host (limpet). This species has not been sequenced and there are no suitable reference genomes that can be used to identify the limpet sequences. Hence it is not possible to remove the limpet sequences and as a result de novo assemblies are highly fragmented and difficult to analyze.

\section{Conclusions}

This study characterizes the metaphylogenome associated with the digestive tract of the seaweed grazing marine limpet $P$. pellucida. By modifying existing DNA extraction protocols, we indirectly extracted enough improved quality microbial DNA to create shotgun libraries, which were analyzed using prokaryotic, clade-specific marker genes. Metagenomic analysis of the microbiome harbored by the limpet indicated an abundance of industrially interesting bacterial groups (Proteobacteria, Firmicutes, and Bacteroidetes), previously identified in other seaweed- or sea grass-grazing animals. The phylogenetic profiles of these three phyla that were characterized through surveying the literature and their potential activities towards the host as well as applications to industry were assessed. Preliminary analysis of the microbial assemblage associated with $P$. pellucida demonstrated the great potential that these three phyla could offer in diverse biorefinery processes as well as the pharmaceutical or bioremediation industries. Future studies including functional metagenomics, metatranscriptomic and comparative genomics are expected to give further insight into the novelty of active bioproducts synthesized by members of this unique microbiome. These results could also benefit microbial ecology by extending the understanding of the relationship between microbes and their marine animal hosts.

\section{Acknowledgments}

This work was supported by the European Regional Development Fund through the Welsh Government for BEACON, grant number 80561.

The authors wish to thank Pippa Moore and Rory Geoghegan for their help with aquarium facilities setup and maintenance as well as Naheed Kaderbhai for her advice and reading the draft.

\section{Author Contributions}

Supervision, direction, concept and securing of funding for research project: Joe Gallagher and Jessica Adams; Performed the experiments: Magda Dudek; Support with the metagenomic DNA extraction: Sharon Huws; Sequenced the metagenomic DNA: Matthew Hegarty; Generated the metagenomic data analysis: Martin Swain; Wrote the paper: Magda Dudek; Revised the paper: Jessica Adams, Joe Gallagher, Martin Swain; Matthew Hegarty. 


\section{Conflicts of Interest}

The authors declare no conflict of interest.

\section{References}

1. Jefreys, J.G. British Conchology: or, an Account of the Mollusca Which Now Inhabit the British Isles and the Surrounding Seas; J. Van Voorst: London, UK, 1865; pp. 242-245.

2. Da Silva, C.M.; Landau, B.M.; Domènech, R.; Martinell, J. Pliocene Atlanto-Mediterranean biogeography of Patella pellucida (Gastropoda, Patellidae): Palaeoceanographic implications. Palaeogeogr. Palaeoclimatol. Palaeoecol. 2006, 233, 225-234.

3. McGrath, D. Recruitment and Growth of the Blue-Rayed Limpet, Helcion Pellucidum (L.), in South East Ireland. J. Molluscan Stud. 1992, 58, 425-431.

4. Taylor, P.; Percival, E. The polysaccharides of green, red and brown seaweeds: Their basic structure, biosynthesis and function. Br. Phycol. J. 1979, 14, 103-117.

5. Jami, E.; Mizrahi, I. Composition and similarity of bovine rumen microbiota across individual animals. PLoS One 2012, 7, e33306

6. Hong, P.Y.; Wheeler, E.; Cann, I.K.O.; Mackie, R.I. Phylogenetic analysis of the fecal microbial community in herbivorous land and marine iguanas of the Galápagos Islands using 16S rRNA-based pyrosequencing. ISME J. 2011, 5, 1461-1470.

7. Eigeland, K. Bacterial community structure in the hindgut of wild and captive dugongs (dugong dugon). Aquat. Mamm. 2012, 38, 402-411.

8. Haygood, M.G.; Schmidt, E.W.; Davidson, S.K.; Faulkner, D.J. Microbial symbionts of marine invertebrates: Opportunities for microbial biotechnology. J. Mol. Microbiol. Biotechnol. 1999, 1, $33-43$.

9. Gomare, S.; Kim, H.A.; Ha, J.H.; Lee, M.W.; Park, J.M. Isolation of the polysaccharidase-producing bacteria from the gut of sea snail, Batillus cornutus. Korean J. Chem. Eng. 2011, 28, 1252-1259.

10. Bakunina, I.I.; Nedashkovskaia, O.I.; Alekseeva, S.A.; Ivanova, E.P.; Romanenko, L.A; Gorshkova, N.M.; Isakov, V.V.; Zviagintseva, T.N.; Mikhălov, V.V. Degradation of fucoidan by the marine proteobacterium Pseudoalteromonas citrea. Mikrobiologiia 2002, 71, 49-55.

11. Gurgui, C.; Piel, J. Metagenomic Approaches to Identify and Isolate Bioactive Natural Products from Microbiota of Marine Sponges. Methods Mol. Biol. Methods Protoc. 2010, 668, 247-264.

12. Zhang, C.; Kim, S.K. Research and application of marine microbial enzymes: Status and prospects. Mar. Drugs 2010, 8, 1920-1934.

13. Demirbas, M.F. Biorefineries for biofuel upgrading: A critical review. Appl. Energy 2009, 86, 151-161.

14. Buonocore, F. Marine Biotechnology: Developments and Perspectives. J. Aquac. Res. Dev. 2012, 4, doi:10.4172/2155-9546.1000e105.

15. Williams, P.G. Panning for chemical gold: Marine bacteria as a source of new therapeutics. Trends Biotechnol. 2009, 27, 45-52.

16. Gilbert, J.A.; Dupont, C.L. Microbial Metagenomics: Beyond the Genome. Annu. Rev. Mar. Sci. 2011, 3, 347-371. 
17. Handelsman, J. Metagenomics: Application of genomics to uncultured microorganisms. Microbiol. Mol. Biol. Rev. 2004, 68, 669-685.

18. Kleiner, M.; Wentrup, C.; Lott, C.; Teeling, H.; Wetzel, S.; Young, J.; Chang, Y.J.; Shah, M; VerBerkmoes, N.C.; Zarzycki, J.; et al. Metaproteomics of a gutless marine worm and its symbiotic microbial community reveal unusual pathways for carbon and energy use. Proc. Natl. Acad. Sci. USA 2012, 109, 1173-1182.

19. Svanevik, C.S.; Lunestad, B.T. Characterisation of the microbiota of Atlantic mackerel (Scomber scombrus). Int. J. Food Microbiol. 2011, 151, 164-170.

20. Thomas, T.; Gilbert, J.; Meyer, F. Metagenomics-A guide from sampling to data analysis. Microb. Inform. Exp. 2012, 2, doi:10.1186/2042-5783-2-3.

21. Kunin, V.; Copeland, A.; Lapidus, A.; Mavromatis, K.; Hugenholtz, P. A bioinformatician's guide to metagenomics. Microbiol. Mol. Biol. Rev. 2008, 72, 557-578.

22. Tringe, S.G.; Rubin, E.M. Metagenomics: DNA sequencing of environmental samples. Nat. Rev. Genet. 2005, 6, 805-814.

23. Harnpicharnchai, P.; Thongaram, T.; Sriprang, R.; Champreda, V.; Tanapongpipat, S.; Eurwilaichitr, L. An efficient purification and fractionation of genomic DNA from soil by modified troughing method. Lett. Appl. Microbiol. 2007, 45, 387-391.

24. Cardoso, A.M.; Cavalcante, J.J.; Cantão, M.E.; Thompson, C.E.; Flatschart, R.B.; Glogauer, A.; Scapin, S.M.; Sade, Y.B.; Beltrão, P.J.; Gerber, A.L.; et al. Metagenomic analysis of the microbiota from the crop of an invasive snail reveals a rich reservoir of novel genes. PLoS One 2012, 7, e48505.

25. Segata, N.; Boernigen, D.; Tickle, T.L.; Morgan, X.C.; Garrett, W.S.; Huttenhower, C. Computational meta'omics for microbial community studies. Mol. Syst. Biol. 2013, 9 , doi:10.1038/msb.2013.22.

26. Huttenhower, C.; Gevers, D.; Knight, R.; Abubucker, S.; Badger, J.H.; Chinwalla, A.T.; Creasy, H.H.; Earl, A.M.; FitzGerald, M.G.; Fulton, R.S. Structure, function and diversity of the healthy human microbiome. Nature 2012, 486, 207-214.

27. Devine, S.P.; Pelletreau, K.N.; Rumpho, M.E. 16S rDNA-based metagenomic analysis of bacterial diversity associated with two populations of the kleptoplastic sea slug Elysia chlorotica and its algal prey Vaucheria litorea. Biol. Bull. 2012, 223, 138-154.

28. Davis, J.; Fricke, W.F.; Haman, M.T.; Esquenazi, E.; Dorrestein, P.C.; Hill, R.T. Characterization of the bacterial community of the chemically defended Hawaiian sacoglossan Elysia rufescens. Appl. Environ. Microbiol. 2013, 79, 7073-7081.

29. Lau, W.W.Y.; Jumars, P.A.; Armbrust, E.V. Genetic diversity of attached bacteria in the hindgut of the deposit-feeding shrimp Neotrypaea (formerly Callianassa) californiensis (decapoda: Thalassinidae). Microb. Ecol. 2002, 43, 455-466.

30. Taylor, M.W.; Radax, R.; Stege, D.R.; Wagner, M. Sponge-associated microorganisms: Evolution, ecology, and biotechnological potential. Microbiol. Mol. Biol. Rev. 2007, 71, 295-347.

31. Isnansetyo, A.; Kamei, Y. Bioactive substances produced by marine isolates of Pseudomonas. J. Ind. Microbiol. Biotechnol. 2009, 36, 1239-1248. 
32. Tamames, J.; Gil, R.; Latorre, A.; Peretó, J.; Silva, F.J.; Moya, A. The frontier between cell and organelle: Genome analysis of "Candidatus Carsonella ruddii”. BMC Evol. Biol. 2007, 7, doi:10.1186/1471-2148-7-181.

33. McCutcheon, J.P.; Moran, N.A. Functional convergence in reduced genomes of bacterial symbionts spanning 200 My of evolution. Genome Biol. Evol. 2010, 2, 708-718.

34. McCutcheon, J.P.; Moran, N.A. Extreme genome reduction in symbiotic bacteria. Nat. Rev. Microbiol. 2012, 10, 13-26.

35. Lim, G.E.; Haygood, M.G. "Candidatus Endobugula glebosa”, a specific bacterial symbiont of the marine bryozoan Bugula simplex. Appl. Environ. Microbiol. 2004, 70, 4921-4929.

36. Davidson, S.K.; Allen, S.W.; Lim, G.E.; Anderson, C.M.; Haygood, M.G. Evidence for the biosynthesis of bryostatins by the bacterial symbiont "Candidatus Endobugula sertula" of the bryozoan Bugula neritina. Appl. Environ. Microbiol. 2001, 67, 4531-4537.

37. Voordeckers, J.W.; Starovoyto, V.V.; Vetriani, C. Caminibacter mediatlanticus sp. nov., a thermophilic, chemolithoautotrophic, nitrate-ammonifying bacterium isolated from a deep-sea hydrothermal vent on the Mid-Atlantic Ridge. Int. J. Syst. Evol. Microbiol. 2005, 55, 773-779.

38. Nakagawa, S.; Takai, K.; Inagaki, F.; Horikoshi, K.; Sako, Y. Nitratiruptor tergarcus gen. nov., sp. nov. and Nitratifractor salsuginis gen. nov., sp. nov., nitrate-reducing chemolithoautotrophs of the epsilon-Proteobacteria isolated from a deep-sea hydrothermal system in the Mid-Okinawa Trough. Int. J. Syst. Evol. Microbiol. 2005, 55, 925-933.

39. Alazard, D.; Dukan, S.; Urios, A.; Verhé, F.; Bouabida, N.; Morel, F.; Thomas, P.; Garcia, J.L.; Ollivier, B. Desulfovibrio hydrothermalis sp. nov., a novel sulfate-reducing bacterium isolated from hydrothermal vents. Int. J. Syst. Evol. Microbiol. 2003, 53, 173-178.

40. Cabrera, G.; Pérez, R.; Gómez, J.M.; Ábalos, A.; Cantero, D. Toxic effects of dissolved heavy metals on Desulfovibrio vulgaris and Desulfovibrio sp. strains. J. Hazard. Mater. 2006, 135, 40-46.

41. Schmidt, I. Chemoorganoheterotrophic growth of Nitrosomonas europaea and Nitrosomonas eutropha. Curr. Microbiol. 2009, 59, 130-138.

42. Musher, D.M. Medical Microbiology, 4th ed.; Baron, S., Ed.; The University of Texas Medical Branch at Galveston: Galveston, TX, USA, 1996.

43. Barns, S.M.; Grow, C.C.; Okinaka, R.T.; Keim, P.; Kuske, C.R. Detection of diverse new Francisella-like bacteria in environmental samples. Appl. Environ. Microbiol. 2005, 71, 5494-5500.

44. Gasparini, R.; Amicizia, D.; Lai, P.L.; Panatto, D. Neisseria meningitidis, pathogenetic mechanisms to overcome the human immune defences. J. Prev. Med. Hyg. 2012, 53, 50-55.

45. Bollmann, A.; Sedlacek, C.J.; Norton, J.; Laanbroek, H.J.; Suwa, Y.; Stein, L.Y.; Klotz, M.G.; Arp, D.; Sayavedra-Soto, L.; Lu, M.; et al. Complete genome sequence of Nitrosomonas sp. Is79, an ammonia oxidizing bacterium adapted to low ammonium concentrations. Stand. Genomic Sci. 2013, 7, 469-482.

46. Foster, G.; Holmes, B.; Steigerwalt, A.G.; Lawson, P.A.; Thorne, P.; Byrer, D.E.; Ross, H.M.; Xerry, J.; Thompson, P.M.; Collins, M.D. Campylobacter insulaenigrae sp. nov., isolated from marine mammals. Int. J. Syst. Evol. Microbiol. 2004, 54, 2369-2373.

47. Perlman, S.J.; Hunter, M.S.; Zchori-Fein, E. The emerging diversity of Rickettsia. Proc. Biol. Sci. 2006, 273, 2097-2106. 
48. Maggi, R.G.; Raverty, S.A.; Lester, S.J.; Huff, D.G.; Haulena, M.; Ford, S.L.; Nielsen, O.; Robinson, J.H.; Breitschwerdt, E.B. Bartonella henselae in captive and hunter-harvested beluga (Delphinapterus leucas). J. Wildl. Dis. 2008, 44, 871-877.

49. Moreno, E.; Cloeckaert, A.; Moriyón, I. Brucella evolution and taxonomy. Vet. Microbiol. 2002, 90, 209-222.

50. Sakaguchi, T.; Arakaki, A.; Matsunaga, T. Desulfovibrio magneticus sp. nov., a novel sulfate-reducing bacterium that produces intracellular single-domain-sized magnetite particles. Int. J. Syst. Evol. Microbiol. 2002, 52, 215-221.

51. Tremaroli, V.; Bäckhed, F. Functional interactions between the gut microbiota and host metabolism. Nature 2012, 489, 242-249.

52. Rabus, R.; Ruepp, A.; Frickey, T.; Rattei, T.; Fartmann, B.; Stark, M.; Bauer, M.; Zibat, A.; Lombardot, T.; Becker, I. The genome of Desulfotalea psychrophila, a sulfate-reducing bacterium from permanently cold Arctic sediments. Environ. Microbiol. 2004, 6, 887-902.

53. Crossman, L.C.; Chen, H.; Cerdeño-Tárraga, A.M.; Brooks, K.; Quail, M.A.; Pineiro, S.A.; Hobley, L.; Sockett, R.E.; Bentley, S.D.; Parkhill, J.; et al. A small predatory core genome in the divergent marine Bacteriovorax marinus SJ and the terrestrial Bdellovibrio bacteriovorus. ISME J. 2012, 1, 148-160.

54. Salf, N.A.L.; Brazier, J.S. The distribution of Clostridium difficile in the environment of South Wales. J. Med. Microbiol. 1996, 45, 133-137.

55. Songsiriritthigul, C.; Lapboonrueng, S.; Pechsrichuang, P.; Pesatcha, P.; Yamabhai, M. Expression and characterization of Bacillus licheniformis chitinase (ChiA), suitable for bioconversion of chitin waste. Bioresour. Technol. 2010, 101, 4096-4103.

56. Trincone, A. Potential biocatalysts originating from sea environments. J. Mol. Catal. B Enzym. 2010, 66, 241-256.

57. Trincone, A. Marine biocatalysts: Enzymatic features and applications. Mar. Drugs 2011, 9, 478-499.

58. Turner, P.; Mamo, G.; Karlsson, E.N. Potential and utilization of thermophiles and thermostable enzymes in biorefining. Microb. Cell Fact. 2007, 23, 1-23.

59. Jang, S.; Shirai, Y.; Uchida, M.; Wakisaka, M. Production of mono sugar from acid hydrolysis of seaweed. J. Biotechnol. 2012, 11, 1953-1963.

60. Van der Wal, H.; Sperber, B.L.; Houweling-Tan, B.; Bakker, R.R.; Brandenburg, W.; López-Contreras, A.M. Production of acetone, butanol, and ethanol from biomass of the green seaweed Ulva lactuca. Bioresour. Technol. 2013, 128, 431-437.

61. Kathiresan, K.; Thiruneelakandan, G. Prospects of lactic acid bacteria of marine origin. Indian J. Biotechnol. 2008, 7, 170-177.

62. Hwang, H.J.; Lee, S.Y.; Kim, S.M.; Lee, S.B. Fermentation of seaweed sugars by Lactobacillus species and the potential of seaweed as a biomass feedstock. Biotechnol. Bioprocess Eng. 2011, $16,1231-1239$.

63. Williams, A.G.; Withers, S.; Sutherland, A.D. The potential of bacteria isolated from ruminal contents of seaweed-eating North Ronaldsay sheep to hydrolyse seaweed components and produce methane by anaerobic digestion in vitro. Microb. Biotechnol. 2013, 6, 45-52. 
64. Hugon, P.; Mishra, A.K.; Robert, C.; Raoult, D.; Fournier, P.E. Non-contiguous finished genome sequence and description of Anaerococcus vaginalis. Stand. Genomic Sci. 2012, 6, 356-365.

65. Miroshnichenko, M.L.; Kublanov, I.V.; Kostrikina, N.A.; Tourova, T.P.; Kolganova, T.V.; Birkeland, N.K.; Bonch-Osmolovskaya, E.A. Caldicellulosiruptor kronotskyensis sp. nov. and Caldicellulosiruptor hydrothermalis sp. nov., two extremely thermophilic, cellulolytic, anaerobic bacteria from Kamchatka thermal springs. Int. J. Syst. Evol. Microbiol. 2008, 58,1492-1496.

66. Wiegel, J.; Ljungdahl, L.G. Thermoanaerobacter ethanolicus gen. nov., spec. nov., a new, extreme thermophilic, anaerobic bacterium. Arch. Microbiol. 1981, 128, 343-348.

67. Herrera, P.; Kwon, Y.M.; Ricke, S.C. Ecology and pathogenicity of gastrointestinal Streptococcus bovis. Anaerobe 2009, 15, 44-54.

68. Murray, H.W.; Roberts, R.B. Streptococcus bovis bacteremia and underlying gastrointestinal disease. Arch. Intern. Med. 1978, 138, 1097-1099.

69. Ivanova, E.P.; Vysotskii, M.V.; Svetashev, V.I.; Nedashkovskaya, O.I.; Gorshkova, N.M.; Mikhailov, V.V.; Yumoto, N.; Shigeri, Y.; Taguchi, T.; Yoshikawa, S. Characterization of Bacillus strains of marine origin. Int. Microbiol. 1999, 2, 267-271.

70. Gunn, B.A.; Colwell, R.R. Numerical taxonomy of Staphylococci isolated from the marine environment. Int. J. Syst. Bacteriol. 1983, 33, 751-759.

71. Vuong, C.; Otto, M. Staphylococcus epidermidis infections. Microbes Infect. 2002, 4, 481-489.

72. Jumas-Bilak, E.; Jean-Pierre, H.; Carlier, J.P.; Teyssier, C.; Bernard, K.; Gay, B.; Campos, J.; Morio, F.; Marchandin, H. Dialister micraerophilus sp. nov. and Dialister propionicifaciens sp. nov., isolated from human clinical samples. Int. J. Syst. Evol. Microbiol. 2005, 55, 2471-2478.

73. Kageyama, A.; Benno, Y. Coprobacillus catenaformis gen. nov., sp. nov., a new genus and species isolated from human feces. Microbiol. Immunol. 2000, 44, 23-28.

74. Barbeyron, T.; L'Haridon, S.; Corre, E.; Kloareg, B.; Potin, P. Zobellia galactanovorans gen. nov., sp. nov., a marine species of Flavobacteriaceae isolated from a red alga, and classification of [Cytophaga] uliginosa (ZoBell and Upham 1944) Reichenbach 1989 as Zobellia uliginosa gen. nov., comb. nov. Int. J. Syst. Evol. Microbiol. 2001, 51, 985-997.

75. Fernández-Gómez, B.; Richter, M.; Schüler, M.; Pinhassi, J.; Acinas, S.G.; González, J.M.; Pedrós-Alió, C. Ecology of marine Bacteroidetes: A comparative genomics approach. ISME J. 2013, 7, 1026-1037.

76. Thomas, F.; Hehemann, J.H.; Rebuffet, E.; Czjzek, M.; Michel, G. Environmental and gut Bacteroidetes: The food connection. Front. Microbiol. 2011, 2, doi:10.3389/fmicb.2011.00093.

77. Pati, A.; Abt, B.; Teshima, H.; Nolan, M.; Lapidus, A.; Lucas, S.; Hammon, N.; Deshpande, S.; Cheng, J.F.; Tapia, R.; et al. Complete genome sequence of Cellulophaga lytica type strain (LIM-21). Stand. Genomic Sci. 2011, 4, 221-232.

78. Ravcheev, D.A.; Godzik, A.; Osterman, A.L.; Rodionov, D.A. Polysaccharides utilization in human gut bacterium Bacteroides thetaiotaomicron: Comparative genomics reconstruction of metabolic and regulatory networks. BMC Genomics 2013, 14, doi:10.1186/1471-2164-14-873.

79. Xie, G.; Bruce, D.C.; Challacombe, J.F.; Chertkov, O.; Detter, J.C.; Gilna, P.; Han, C.S.; Lucas, S.; Misra, M.; Myers, G.L.; et al. Genome sequence of the cellulolytic gliding bacterium Cytophaga hutchinsonii. Appl. Environ. Microbiol. 2007, 73, 3536-3546. 
80. López-Sánchez, M.J.; Neef, A.; Peretó, J.; Patiño-Navarrete, R.; Pignatelli, M.; Latorre, A.; Moya, A. Evolutionary convergence and nitrogen metabolism in Blattabacterium strain Bge, primary endosymbiont of the cockroach Blattella germanica. PLoS Genet. 2009, 5, e1000721.

81. Mirande, C.; Kadlecikova, E.; Matulova, M.; Capek, P.; Bernalier-Donadille, A.; Forano, E.; Béra-Maillet, C. Dietary fibre degradation and fermentation by two xylanolytic bacteria Bacteroides xylanisolvens XB1AT and Roseburia intestinalis XB6B4 from the human intestine. J. Appl. Microbiol. 2010, 109, 451-460.

82. Lawson, P.A.; Moore, E.; Falsen, E. Prevotella amnii sp. nov., isolated from human amniotic fluid. Int. J. Syst. Evol. Microbiol. 2008, 58, 89-92.

83. Gronow, S.; Munk, C.; Lapidus, A.; Nolan, M.; Lucas, S.; Hammon, N.; Deshpande S.; Cheng, J.F.; Tapia, R.; Han, C.; et al. Complete genome sequence of Paludibacter propionicigenes type strain (WB4T). Stand. Genomic Sci. 2011, 4, 36-44.

84. Pagani, I.; Chertkov, O.; Lapidus, A.; Lucas, S.; del Rio, T.G.; Tice, H.; Copeland, A.; Cheng J.F.; Nolan, M.; Saunders, E.; et al. Complete genome sequence of Marivirga tractuosa type strain (H-43). Stand. Genomic Sci. 2011, 4, 154-62.

85. Yoon, J.H.; Kang, S.J.; Oh, T.K. Algoriphagus locisalis sp. nov., isolated from a marine solar saltern. Int. J. Syst. Evol. Microbiol. 2005, 55, 1635-1639.

86. Liolios, K.; Sikorski, J.; Lu, M.; Nolan, M.; Lapidus, A.; Lucas, S.; Hammon, N.; Deshpande, S.; Cheng, J.F.; Tapia, R. Complete genome sequence of the gliding, heparinolytic Pedobacter saltans type strain (113). Stand. Genomic Sci. 2011, 5, 30-40.

87. Yabuuchi, E.; Kaneko, T.; Yano, I.; Moss, C.W.; Miyoshi, N. Sphingobacterium, gen. nov., Sphingobacterium spiritivorum comb. nov., Sphingobacterium multivorum comb. nov., Sphingobacterium mizutae sp. nov., and Flavobacterium indologenes sp. nov.: Glucose-nonfermenting gram-negative rods in CDC groups IIK-2 and IIb. Int. J. Syst. Evol. Microbiol. 1983, 33, 580-598.

88. Pankratov, T.A.; Tindall, B.J.; Liesack, W.; Dedysh, S.N. Mucilaginibacter paludis gen. nov., sp. nov. and Mucilaginibacter gracilis sp. nov., pectin-, xylan- and laminarin-degrading members of the family Sphingobacteriaceae from acidic Sphagnum peat bog. Int. J. Syst. Evol. Microbiol. 2007, 57, 2349-2354.

89. Glavina del Rio, T.; Abt, B.; Spring, S.; Lapidus, A.; Nolan, M.; Tice, H.; Copeland, A.; Cheng, J.F.; Chen, F.; Bruce, D. Complete genome sequence of Chitinophaga pinensis type strain (UQM 2034). Stand. Genomic Sci. 2010, 2, 87-95.

90. Kendall, M.M.; Liu, Y.; Sieprawska-Lupa, M.; Stetter, K.O.; Whitman, W.B.; Boone, D.R. Methanococcus aeolicus sp. nov., a mesophilic, methanogenic archaeon from shallow and deep marine sediments. Int. J. Syst. Evol. Microbiol. 2006, 56, 1525-1529.

91. Van der Maarel, M.J.; Artz, R.R.; Haanstra, R.; Forney, L.J. Association of marine archaea with the digestive tracts of two marine fish species. Appl. Environ. Microbiol. 1998, 64, 2894-2898.

92. Preston, C.M.; Wu, K.E.Y.; Molinskit, T.F.; Delong, E.F. A psychrophilic crenarchaeon inhabits a marine sponge: Cenarchaeum symbiosum gen. nov., sp. nov. Proc. Natl. Acad. Sci. USA 1996, 93, 6241-6246.

93. Caswell, J.L.; Bateman, K.G.; Cai, H.Y.; Castillo-Alcala, F. Mycoplasma bovis in respiratory disease of feedlot cattle. Vet. Clin. N. Am. Food Anim. Pract. 2010, 26, 365-379. 
94. Gupta, R.S.; Mahmood, S.; Adeolu, M. A phylogenomic and molecular signature based approach for characterization of the phylum Spirochaetes and its major clades: Proposal for a taxonomic revision of the phylum. Front. Microbiol. 2013, 4, doi:10.3389/fmicb.2013.00217.

95. Sitnikova, T.; Michel, E.; Tulupova, Y.; Khanaev, I.; Parfenova, V.; Prozorova, L. Spirochetes in gastropods from Lake Baikal and North American freshwaters: New multi-family, multi-habitat host records. Symbiosis 2012, 56, 103-110.

96. Chen, J.G.; Lou, D.; Yang, J.F. Isolation and Identification of Acholeplasma sp. from the Mud Crab, Scylla serrata. Evid. Based Complement. Altern. Med. 2011, 2011, doi:10.1155/2011/209406.

97. Strauss, J.; Kaplan, G.G.; Beck, P.L.; Rioux, K.; Panaccione, R.; Devinney, R.; Lynch, T.; Allen-Vercoe, E. Invasive potential of gut mucosa-derived Fusobacterium nucleatum positively correlates with IBD status of the host. Inflamm. Bowel Dis. 2011, 17, 1971-1978.

98. Keenan, S.W.; Engel, A.S.; Elsey, R.M. The alligator gut microbiome and implications for archosaur symbioses. Sci. Rep. 2013, 3, doi:10.1038/srep02877.

99. Van den Burg, B. Extremophiles as a source for novel enzymes. Curr. Opin. Microbiol. 2003, 6, 213-218.

100. Bull, A.T.; Stach, J.E.M. Marine Actinobacteria: New opportunities for natural product search and discovery. Trends Microbiol. 2007, 15, 491-499.

101. Alex, A.; Vasconcelos, V.; Tamagnini, P.; Santos, A.; Antunes, A. Unusual symbiotic Cyanobacteria association in the genetically diverse intertidal marine sponge Hymeniacidon perlevis (Demospongiae, Halichondrida). PLoS One 2012, 7, e51834.

102. Ross, L.G.; Ross, B. Anaesthetic and Sedative Techniques for Aquatic Animals, 3rd ed.; Blackwell Publishing: Oxford, UK, 2008.

103. Aronesty, E. Comparison of sequencing utility programs. Open Bioinform. J. 2013, 7, 1-8.

(C) 2014 by the authors; licensee MDPI, Basel, Switzerland. This article is an open access article distributed under the terms and conditions of the Creative Commons Attribution license (http://creativecommons.org/licenses/by/4.0/). 